\title{
Одномодовая накачка мощного усилителя одномодового непрерывного узкополосного излучения на маломодовом активном иттербиевом волокне как метод повышения порога модовой нестабильности
}

\author{
А.А. Сурин ${ }^{1, *}, \underline{\text { И.В. Шебаршина }}{ }^{2}$,А.А. Мольков ${ }^{1,2}$, К.Ю. Прусаков ${ }^{1,2}$ \\ ${ }^{1}$ НТО “ИРЭ-Полюс”, Фрязино \\ ${ }^{2}$ Московский Физико-Технический Институт (ГУ), Москва \\ *E-mail: aSurin@ntoire-polus.ru
}

DOI: 10.31868/RFL2020.55-56

Источники непрерывного лазерного излучения (ИК и видимого диапазона) с узкой спектральной линией (<<1 ГГц) широко востребованы в различных прикладных задачах и фундаментальных исследованиях, таких как, например, голография, медицина или спектроскопия. Также источники мощного (> 10 Вт) линейнополяризованного узкополосного излучения ИК диапазона представляют особый интерес как источники накачки для получения излучения видимого диапазона в процессе нелинейно-оптического преобразовании излучения в кристаллах $\mathrm{c}$ периодической доменной структурой.

Для получения мощного узкополосного линейно-поляризованного излучения на практике используется МОРА-схема (Master Oscillator Power Ampllifier: задающий лазер + усилитель) [1]. В этом случае маломощное $(\sim 100 \mathrm{MBT})$ излучение задающего узкополосного лазера (например, полупроводникового лазера) усиливается в активном волокне. Одной из наиболее распространённых сред для получения излучения в области 1 мкм является активное волокно, легированное ионами иттербия. Когда речь идёт об усилении узкополосного сигнала в волоконном усилителе, то усиление происходит, как правило, в нескольких усилительных каскадах, разделённых оптическими изоляторами [2], с целью не допустить усиления спонтанного излучения в обратном направлении, а также повысить порог возникновения вынужденного рассеяния Мандельштама-Бриллюэна (ВРМБ), который зависит от суммарной длины оптического тракта и интенсивности излучения. Чтобы сократить длину волокна и увеличить площадь моды, сохранив при этом величину усиления, необходимы изменения геометрии активного волокна, и это приведёт к тому, что активное волокно перестанет быть одномодовым, а станет маломодовым. Усиление узкополосного сигнала в маломодовых активных волокнах ограничено, в свою очередь, возникновением такого явления, как модовая нестабильность (МН) [3].

В данной работе развивается подход для повышения порога $\mathrm{MH}$, предложенный в [4], для получения узкополосного (< 100 МГц) излучения на 1064 нм путём усиления слабого узкополосного сигнала в усилителе на маломодовом активном волокне, легированном ионами иттербия. На рисунке 1 представлена оптическая схема эксперимента. В качестве активной среды использовалось маломодовое активное волокно, легированное ионами $\mathrm{Yb}^{3+}$, с концентрацией активных ионов $5400 \mathrm{ppm}$ и диаметром моды 10,5 мкм, разваренное согласованным по моде пассивным волокном. На свободном конце выходного сигнального волокна был сделан косой скол для снижения обратных отражений (понижения порога ВРМБ и предотвращения паразитной генерации). Весь оптический тракт собран на волокнах, поддерживающих поляризацию. 
В качестве задающего источника линейно-поляризованного излучения 1064 нм был использован полупроводниковый лазерный диод, мощность которого составляла 200 мВт. В качестве источника накачки использовался непрерывный мощный линейно поляризованный одномодовый лазер, излучающий на 1030 нм, разработки НТО «ИРЭПолюс». Излучение задающего лазера и лазера накачки объединяется с помощью волоконного объединителя WDM (Wave Division Multiplexor).

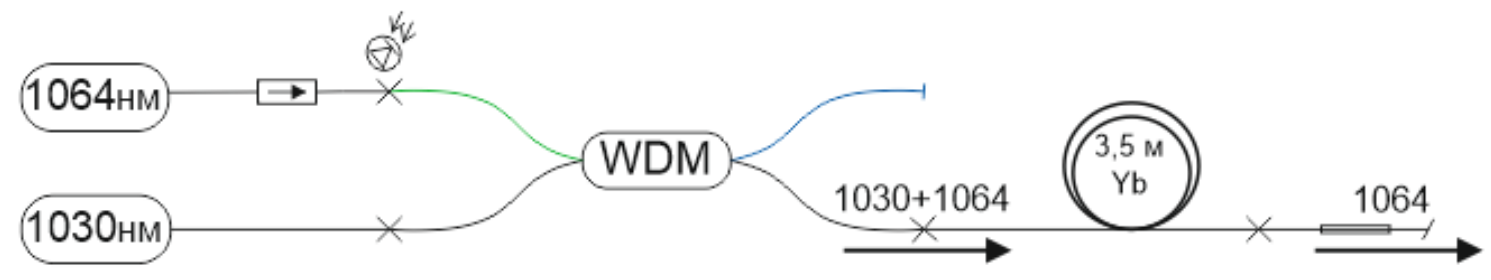

Рис.1. Оптическая схема усилителя узкополосного излучения на длине волны 1064 нм.

В данной схеме было получено до 50 Вт линейно-поляризованного, одномодового излучения на длине волны 1064 нм с дифференциальной эффективностью 80\%. При этом МН не возникала, что говорит об увеличении порога данного эффекта более, чем на порядок, по сравнению с использованием многомодовой диодной накачки усилителя на длине волны 975 нм, где порог МН достигался уже при выходной мощности менее 1 Вт. Дальнейшее повышение выходной мощности в представленной оптической схеме ограничивается возрастанием обратного сигнала, которое обусловлено возникновением в схеме ВРМБ.
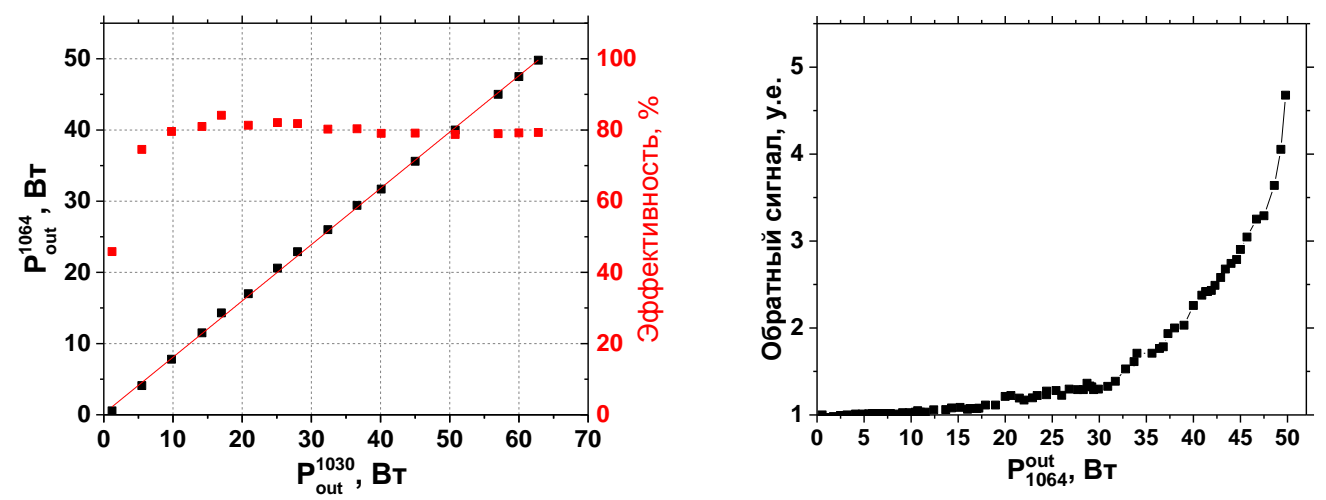

Рис. 2. Зависимость полученной выходной мощности излучения на длине волны 1064 нм и эффективность преобразования в зависимости от мощности одномодовой накачки на 1030 нм (слева); возрастание обратного сигнала в зависимости от выходной мощности (справа).

Авторы выражают благодарность руководству НТО «ИРЭ-Полюс» за поддержку данных исследований.

\section{Литература}

[1] J. Li, S. H. Yang et al, Laser Phys. 20, 1806-1809 (2010)

[2] L. Zhang, S. Cui et al, Opt. Express 21, 5456 (2013)

[3] M. Kuznetsov, O. Vershinin et al, Opt. Express 22, 29714 (2014)

[4] A. A. Surin, A. A. Molkov et al, Quantum Electron. 48, 1095-1098 (2018) 